\title{
Evaluation of Children with Extremity Fracture Occurred as a Result of Motor Vehicle Injury
}

\author{
Motorlu Taşıt Yaralanması Nedeniyle Ekstremite Kırığı Gelişen Çocukların \\ Değerlendirilmesi
}

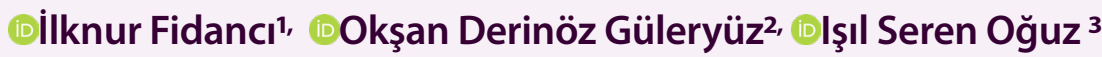 \\ 'Department of Pediatric Emergency Medicine. University of Health Sciences Ankara Training and Education Hospital. Turkey \\ 2Department of Pediatric Emergency Medicine: Medical Faculty of Gazi University. Turkey \\ ${ }^{3}$ Department of Pediatrics. Medical Faculty of Gazi University. Turkey
}

\section{ABSTRACT}

Aim: The aim of the study was to examine and evaluate patients with extremity fractures who admitted to the Pediatric emergency service due to a motor vehicle accident, whether there was any accompanying additional organ injury, and fracture patterns according to the severity of the trauma.

Material and Method: The study was conducted between January 2015 and 2020 retrospectively. Relevant data were analyzed with IBM SPSS V23 statistics.

Results: Of the 205.710 patients who admitted to Pediatric emergency service in the course of this study, $1.378(0.66 \%)$ experienced motor vehicle injuries. $161(0.08 \%)$ of these cases were evaluated on the grounds of extremity fractures. Mean age of the cases were 133 months (minimum: 3, maximum: 2018 months) and 90 (56\%) cases were male. Trauma type was mostly outside-vehicle traffic accident (50\%). $55 \%$ of the cases were severe mechanism of injury. The most common lower extremity fracture type was the tibia (26\%) fracture. The most common fractures in the upper extremity were humerus $(16 \%)$ and radius (16\%) fractures. Of the patients with pelvis fracture, $65 \%$ had other types of organ injuries $(p<0.05)$. Surgical treatment was admitted to $68 \%$ of those with femoral fractures and $43 \%$ of those with tibia fractures $(p<0.05)$. While lower extremity fractures were more common in outside-vehicle traffic accident (66\%) and motorcycle accident (60\%), upper extremity fracture was more common in intra-vehicle traffic accident $(54 \%)(p<0.05)$.

Conclusion: Since the literature evaluating the extremity fractures in motor vehicle accidents is very limited, relevant data are also very limited. Extremity fractures that occur especially after motor vehicles are an important cause of injuries and deaths, and impose a heavy burden upon both families and the government in terms of hospital stay and hospital costs.

Keywords: Pediatric emergency, motor vehicle injury, extremity fractures

\section{ÖZ}

Amaç: Çocuk Acil Servise motorlu araç kazası nedeniyle başvuran extremite kırığı mevcut olan hastaları, beraberinde ek organ yaralanması olup olmadığını, trvamanın şiddetine göre kırık paternlerini inceleyip değerlendirmeyi amaçladık.

Gereç ve Yöntem: Ocak 2015 ve Ocak 2020 tarihleri arasında motorlu araç kazasıyla başvuran ekstremite kırığı olan hastalarda retrospektif olarak yapılmıştır. Veriler IBM SPSS V23 ile analiz edildi.

Bulgular: Çalışma süresince Çocuk Acil Servise 205.710 hasta başvurmuş olup, 1.378 (\% 0,66)'i motorlu taşıt yaralanmasıdır. Bu olgularında $161 \quad(\% 0,08)^{\prime} i$ ekstremite kırığı nedeniyle değerlendirilmiştir. Olguların yaş ortalaması 133 ay (minimum:3; maksimum:218ay) dır ve 90 (\%56) olgu erkektir. Travma şekli daha çok ADTK (\%50) idi. \%55 i yüksek enerjili travmaydı. Alt extremite kırıklarından en sık görüleni tibia (\%26) kırığıydı. Üst extremitede kırıklarından en sık görüleni humerus (\%16) ve radius (\%16) kırıklarıydı. Pelvis krığı olan hastaların \%65 inde başka organ yaralanması vardı $(p<0,05)$. Hastaların büyük kısmına (\%66) tedavide atel uygulanırken, \%26 sına cerrahi operasyon yapılmışıır. Femur kırı̆̆ı olanların \%68 ine, tibia kırığı olanların \%43 üne cerrahi tedavi uygulandı $(p<0,05)$. Hastaların \%50,3 ü acilden taburcu edildi. Alt extremite kıı̆ğı ADTK (\%66) ve motosiklet kazası (\%60) sonucu daha çok görülürken, Üst extremite kırı̆̆ı AiTK (\%54) sonucu daha çok görüldü $(p<0,05)$

Sonuç: Motorlu taşıt kazalarında extremite kırıklarının incelendiği literatür çok kısıtlı olduğundan, verilerde çok sınırlıdır. Özellikle motorlu araç sonrası gelişen extremite kırıkları sakatıklar ve ölümlerin önemli bir nedeni ve hastanede kalış ve hastane maliyeti açısından da hem ailelere hem de devlete ağır bir yük oluşturur.

Anahtar kelimeler: Çocuk acil, motorlu araç yaralanması, ekstremite kırıklar 


\section{INTRODUCTION}

Motor vehicle injuries are caused by motor-driven motorcycles, automobiles, trucks, minibuses, trains, trams, tractors, and land vehicles. Motor vehicle injuries play critical role in casualties and labor loss in developed and developing countries (1). Across the globe, due to trauma caused by motor vehicle injuries, more than 3.000 people die every day, and about 1.2 million people each year $(2,3)$.

Of the emergency service applications in developing countries, $30-86 \%$ are due to trauma caused by motor vehicle injuries. Current data on injuries indicate that driving motor vehicle without helmet and seat belt accounts for more than $50 \%$ of driver casualties (4).

Serious injuries caused by motor vehicle accident are traumatic brain injury, spinal cord injury, generalized burns in the body, amputation and blindness (5). Fractures occur at a ratio of $10-25 \%$ among all childhood traumas. Occurrence frequency is $50 \%$ in boys and $30 \%$ in girls. Fracture pattern has a changeability depending on the countries, climatic characteristics and cultural features (6). Extremity fractures constitute $80-90 \%$ of all fractures. The type and pattern of extremity fractures also vary as per the age, mechanism of injury, and involvement of surrounding tissues (7). Bone periosteum of children are thicker, stronger, has a significant osteogenic potential, and are more active metabolically. In regard of these characteristics, children fractures are easier to heal. Thicker periosteum prevents fracture displacement and compound fractures (8).

Extremity fractures caused by motor vehicle accidents are essential as they can lead to morbidity and disabilities. Lower extremity fractures, upon which limited number of studies were conducted in literature, were analyzed in one of the studies evaluating few adult and pediatric patients. Of the samples, most of them were adults between the ages of 20-40, stressing the fact that this is due to population being consisted of actively working adults who have a higher potential to use motor vehicles.

In this study, we conducted a retrospective analysis regarding the patients with extremity fractures who admitted to the Pediatric emergency service due to a motor vehicle accident, whether there was any accompanying additional organ injury, and fracture patterns according to the severity of the injury, and aimed to emphasize the importance of protective and preventive measures and equipment and traffic rules to prevent mortality and disabilities.

\section{MATERIAL AND METHOD}

\section{Study Design}

This study was conducted retrospectively between January 2015 and 2020 at urban, tertiary pediatric emergency service. Ethics committee approval was received by the medical faculty scientific research ethics committee prior to the study (No: 09.05.2020/ 91610558604.01.02-).

\section{Patient Selection and Data Collection}

All patients younger than 18 years old with a fracture of an extremity due to a motor vehicle accident who admitted directly or brought by ambulance to the pediatric emergency service were included in the study. Demographic data of the patients such as age, gender, type of trauma, fracture extremity, fracture type, number of fractures, treatment and follow-up were recorded.

\section{Definitions}

Motor vehicle injuries are injuries caused by motordriven motorcycles, automobiles, trucks, minibuses, trains, trams, tractors, and land vehicles (9).

Severe mechanism of injury is defined as overturning as a result of a motor vehicle accident, ejection from the vehicle, having a casualty inside the vehicle, collapse failure of more than $50 \mathrm{~cm}$ on the driver's side, collapse failure of more than $30 \mathrm{~cm}$ on the passenger side, being stuck the vehicle for more than 20 minutes, motorcycle accident without helmet, running down a pedestrian with a vehicle or a motorcycle, and speeding up to 65 $\mathrm{km} / \mathrm{h}(10)$.

Multiple fractures are evaluated as the presence of more than one long bone fracture in the patient.

\section{Statistical Analysis}

Data were analyzed with IBM SPSS V23 statistics. Chisquare and One-way Anova tests were used in the comparison of categorical data. T test was used in the comparison of ages of the patients. Analysis results were presented as frequency (percentage) for categorical data, mean and standard deviation for numerical data. Significance level was taken as $p<0.05$

\section{RESULTS}

Of the 205.710 patients who admitted to Pediatric emergency service in the course of this study, 1.378 $(0.66 \%)$ were motor vehicle injuries. $161(0.08 \%)$ of these cases were evaluated on the grounds of extremity fractures (Figure 1). Mean age of the cases were 133 months (minimum: 3, maximum: 2018 months) and 90 (56\%) cases were male. Demographic information of the patients who constitute the study group were presented in Table 1.

Of the patients, $52 \%$ (80) had low extremity fracture localization. The most common lower extremity fracture type was the tibia (26\%) fracture, followed by femoral $(n=28,17 \%)$, fibula $(n=28,17 \%)$, and pelvis fractures $(n=20,12 \%)$ respectively. The most common upper 


\section{Table 1: Demographic data of}

the patients

Age (months) min-max

Gender

Male

Female

Application time

08:00-16:00

16:00-00:00

00:01-07:59

Trauma types

Intra-vehicle traffic accident

Outside-vehicle traffic accident

Motorcycle

Severe mechanism of injury

Yes

No

Type of Severe mechanism of injury

Overturning as a Result of a Motor

Vehicle Accident

Casualty status

Collapse failure of more than $50 \mathrm{~cm}$

Collapse failure of more than $30 \mathrm{~cm}$ on the passenger side

Being stuck in the vehicle for more than

20 minutes

Motorcycle Accident without Helmet

Running Down a Pedestrian With a

Vehicle or a Motorcycle

Speeding up to $65 \mathrm{~km} / \mathrm{h}$

Fracture Localization

Upper

Lower

Upper and lower extremity

Fracture Type

Compound Fracture

Closed Fracture

Compound+closed fracture

Checkup

Discharged from emergency department Yes

No

Follow-up in other units

Pediatrics

Pediatric intensive care

Orthopedics

Pediatric surgery

Treatment

Air Splint

Yes $\mathbf{n}(\%)$

Plaster

Surgery

Other organ injury

Liver

Yes $\mathbf{n}(\%)$

Lungs

Intestines

Stomach

Pancreas

Kidney

Central Nervous System
$80(49.7)$

$13(8)$

$34(21)$

17 (11)

No n (\%)

$106(66)$

22 (14)

$42(26)$

14 (9)

4 (2.5)

$23(14)$

1 (1)

$0(0)$

7 (4)

1 (1)

n (\%)

$90(56)$

$71(44)$

$63(39)$

79 (49)

15 (9)

$71(44)$

$80(50)$

$10(6)$

$89(55)$

$72(45)$

21 (13)

2 (8)

(2)

15 (9)

21 (13)

67 (42)

84 (52)

$10(6)$

(1)

55 (34)

139 (86)

119 (74)

No n (\%)

147 (91)

157 (97.5)

160 (99)

$161(100)$

154 (96)

160 (99)

4 (2.5)
157 (97.5)
$138(86)$ extremity fracture type was humerus $(n=26,16 \%)$ and radius $(n=26,16 \%)$ fractures, followed by clavicula $(n=23,14 \%)$ and ulna $(n=8,5 \%)$ fractures respectively. While shaft fractures were more common in femoral fracture type, distal fractures were more common in the tibia and fibula fracture types, and proximal fractures were more common in the humerus fracture types (Figure 2, 3).

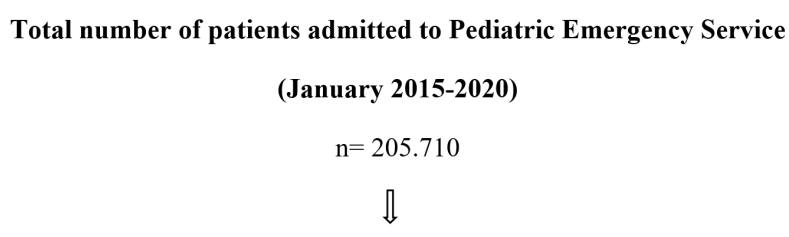

Number of patients admitted with a motor vehicle accident

$$
\begin{gathered}
\mathrm{n}=1.378(0.66 \%) \\
\rrbracket
\end{gathered}
$$

Number of cases of limb fracture

$\mathrm{n}=161(0.08 \%)$

Figure 1. Patients Admitted to Pediatric Emergency Service

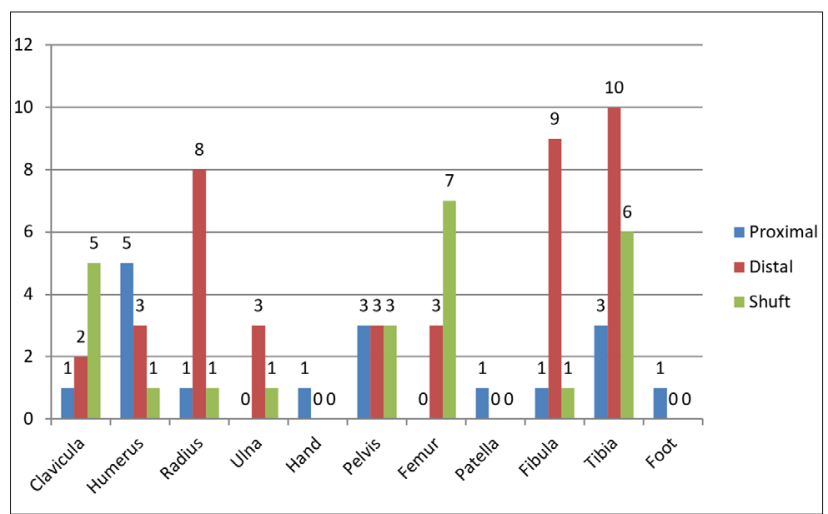

Figure 2. Extremity bone fracture incidence ratio for the right side (\%) *Total ratio for Patella, Hand, and Foot were indicated in the proximal part, without distinction of proximal, distal, shaft fractures.

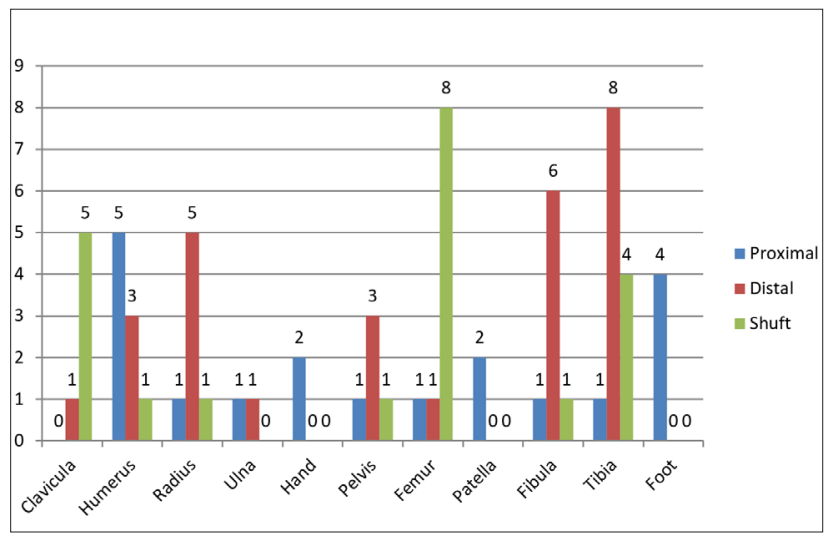

Figure 3. Extremity bone fracture incidence ratio for the left side (\%) *Total ratio for Patella, Hand, and Foot were indicated in the proximal part, without distinction of proximal, distal, shaft fractures. 
Evaluating the fracture localization as per the age groups, it was observed that the upper extremity fractures in 13 (50\%) patients under the age of 5 were more common while lower extremity fractures in 29 (54.7\%) patients aged 5-11 and 44 (53.4\%) patients over the age of 11 were more common. Of the patients with lower extremity fractures, 44 (52.4\%) consisted of children over the age of 11 (Table 2). The ratio of all the fracture types were more common in children over the age of 11 (Figure 4).

\begin{tabular}{|c|c|c|c|c|}
\hline \multirow[b]{2}{*}{ Age Groups } & \multicolumn{3}{|c|}{ Fracture localization } & \multirow[b]{2}{*}{$\mathbf{p}$} \\
\hline & $\begin{array}{c}\text { Upper } \\
\text { Extremity } \\
\text { n (\%) }\end{array}$ & $\begin{array}{c}\text { Lower } \\
\text { Extremity } \\
\text { n (\%) }\end{array}$ & $\begin{array}{l}\text { Both } \\
\text { n (\%) }\end{array}$ & \\
\hline 5 years $>$ & & & & 0.109 \\
\hline yes & 13(19.4) & $11(13.1)$ & $2(20)$ & \\
\hline no & $54(80.6)$ & $73(86.9)$ & $8(80)$ & \\
\hline $5-11 y$ & & & & 0.080 \\
\hline yes & 20(29.9) & $29(34.5)$ & $4(40)$ & \\
\hline no & $47(69.1)$ & $55(65.5)$ & $6(60)$ & \\
\hline $11 y<$ & & & & 0.076 \\
\hline yes & $34(50.7)$ & $44(52.4)$ & $4(40)$ & \\
\hline no & $33(49.3)$ & $40(47.6)$ & $6(60)$ & \\
\hline
\end{tabular}

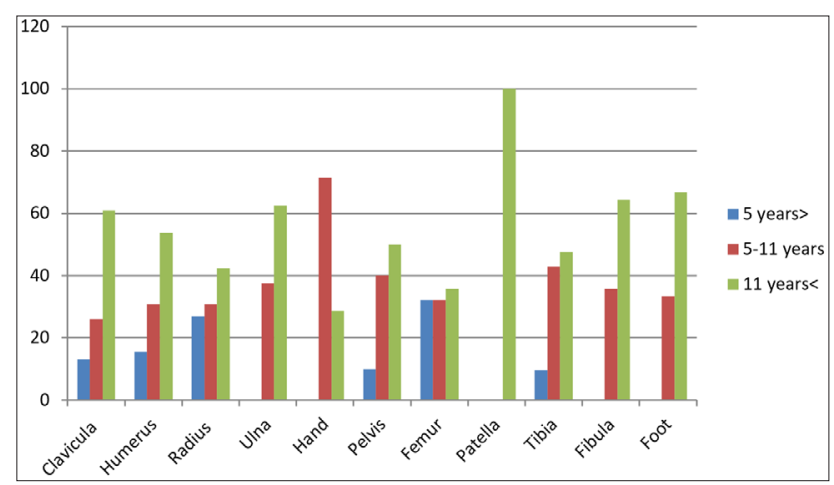

Figure 4. Extremity bone fractures by age groups (\%)

Femoral, pelvis, fibular fractures and other organ injuries were statistically significantly high in the patients who admitted hospitals due to severe mechanism of injury $(p<0.05)$. Additionally, $83 \%$ of the compound fractures occurred due to severe mechanism of injury (Table $\mathbf{3}$ ).

While upper extremity fractures were statistically significantly high in severe mechanism of injury patient group who experienced overturning as a result of a motor vehicle accident, ejection from the vehicle, and those who had a casualty inside the vehicle; lower extremity fractures were more common in the patient groups who experienced motorcycle accident without helmet, pedestrian versus motor vehicle accident and those speeding up to $65 \mathrm{~km} / \mathrm{h}(\mathrm{p}<0,05)$. While most of the patients who had upper extremity fractures were treated with air splint or encased in plaster, lower extremity fracture cases required surgical treatment (Table 4).

Of the patients with femoral fracture, $68 \%$ were surgically treated $(p<0.05)$. The ratio of other organ injuries occurred in the patients with pelvis fracture were $65 \%$ $(\mathrm{p}<0.05)$ (Table 5).

Table 3. The relationship between severe mechanism of injury and fracture location, fracture type, and other organ injury

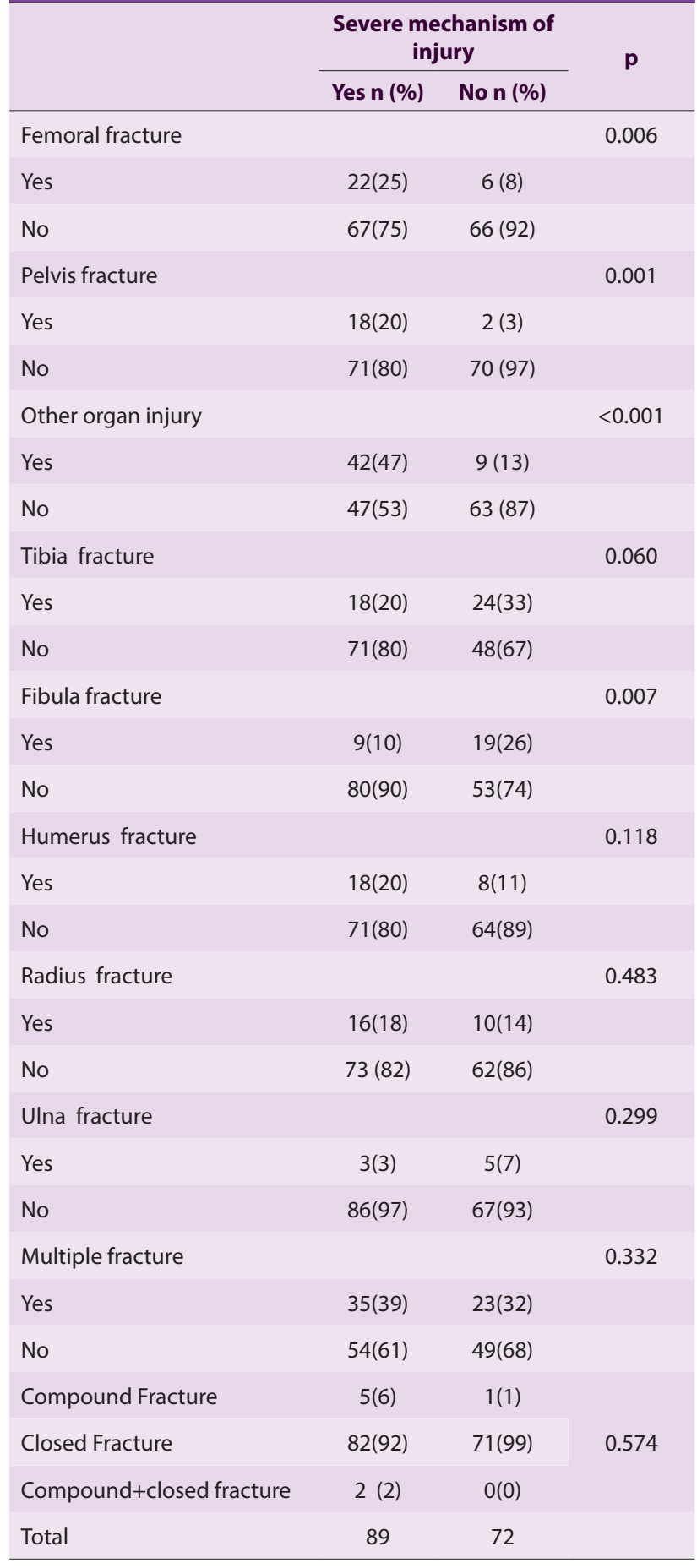


Table 4. Comparison of fracture location and severe mechanism of injury type and treatment modality

\begin{tabular}{|c|c|c|c|c|}
\hline Type of severe mechanism of injury & $\begin{array}{c}\text { Fracture } \\
\text { localization } \\
\text { Upper ext. }\end{array}$ & Lower ext. & Upper+lower ext. & $\mathbf{p}$ \\
\hline Overturning as a result of a motor vehicle accident & $11(52)$ & $9(43)$ & 1(5) & \multirow{9}{*}{0.028} \\
\hline Ejection from the vehicle, & $4(57)$ & $3(43)$ & $0(0)$ & \\
\hline Casualty status & $7(58)$ & $3(25)$ & $2(17)$ & \\
\hline Collapse failure of more than $50 \mathrm{~cm}$ & 1(33) & 1(33) & 1(33) & \\
\hline Collapse failure of more than $30 \mathrm{~cm}$ on the passenger side & $1(50)$ & 0 & 1(50) & \\
\hline Being stuck in the vehicle for more than 20 minutes & 0 & $2(50)$ & $2(50)$ & \\
\hline Motorcycle accident without helmet & $1(25)$ & $3(75)$ & 0 & \\
\hline Running down a pedestrian with a vehicle or a motorcycle & 6(40) & $8(53)$ & 1(7) & \\
\hline Speeding up to $65 \mathrm{~km} / \mathrm{h}$ & $3(14)$ & $17(81)$ & 1(5) & \\
\hline \multicolumn{5}{|l|}{ Treatment modality } \\
\hline \multicolumn{5}{|l|}{ Air Splint } \\
\hline Yes & $51(76)$ & $47(56)$ & $8(80)$ & \\
\hline No & $16(24)$ & $37(44)$ & $2(20)$ & \\
\hline \multicolumn{5}{|l|}{ Plaster } \\
\hline Yes & $6(9)$ & $14(17) 70(83)$ & $2(20)$ & \\
\hline No & $61(91)$ & & $8(80)$ & \\
\hline Surgical Treatment & & $29(35)$ & & \\
\hline Yes & $6(9)$ & $55(65)$ & $7(70)$ & \\
\hline No & $61(91)$ & & $3(30)$ & \\
\hline
\end{tabular}

Table 5. Correlation of fracture location and surgical treatment.

\begin{tabular}{lccc}
\multirow{2}{*}{$\begin{array}{l}\text { Fracture } \\
\text { localization }\end{array}$} & \multicolumn{2}{c}{ Surgical Treatment } & \\
\cline { 2 - 3 } Femoral fracture & Yes $\mathbf{n}(\%)$ & No $\mathbf{n}(\%)$ & $\mathbf{p}$ \\
Yes & $19(68)$ & $9(32)$ & \\
No & $23(17)$ & $110(83)$ & \\
Tibia fracture & & & 0.001 \\
Yes & $18(43)$ & $24(57)$ & \\
No & $24(20)$ & $95(80)$ & \\
Pelvis fracture & & & 0.004 \\
Yes & $4(20)$ & $16(80)$ & \\
No & $3(2)$ & $138(98)$ & \\
\hline
\end{tabular}

\section{DISCUSSION}

Motor vehicle accidents have an important place among childhood traumas and they are the leading cause of death in children aged 2-14 years in developed countries (11). Motor vehicle accidents consist of $30 \%$ of the trauma-related casualties aged between 0-19 (12). Fractures are common among injuries in the childhood age group (13). Extremity fractures are among the most common reasons for hospitalization in children (14). While there were not many articles previously studying extremity fractures occur in motor vehicle accidents, in the present study, male dominance (56\%) was observed in line with the results of studies evaluating childhood fractures $(15,6)$.

Lower extremity fractures constitute approximately $20 \%$ of all fractures occur in children and may cause significant mortality and morbidity (16). In the study of Ngunde et al., the incidence ratio of lower extremity fractures in patients experienced a motor vehicle accident was found to be $35 \%$ (4). In a study conducted with adult patients, the lower extremity fracture was detected 3 times more than the upper extremity fracture occurred in motor vehicle accident (3). Of the patients included in this study, 52\% had lower extremity fracture. Evaluating the age groups, lower extremity fracture was mostly seen in the patient group over 11 years of age. We can conclude that in conjunction with the growth, children will be as tall as the vehicles and along with it, lower extremity risk also increases.

Lower extremity fractures were also significantly higher in patients who admitted to hospital for severe mechanism of injury (particularly a motorcycle accident without a helmet, running off a pedestrian, speeding up to $65 \mathrm{~km} /$ h). In line with the literature, mostly tibia fracture (26\%) was observed in the lower extremity $(15,17)$.

In accordance with the literature (18), shaft fractures were more common in the femur, while distal fractures were prominent in the tibia and fibula. In addition, femoral fractures caused by a motor vehicle accident were mostly treated surgically in this study, as was detected in other studies conducted (19).

$43 \%$ of tibia fractures required surgical operation. For that reason, it is of great importance that the parents adhere to the traffic rules, display sensitivity as regards the safety equipment such as safety belt, helmet, and bring them to bear on their children without compromising.

Pediatric pelvic fractures occur in $0.2 \%$ to $2 \%$ of all pediatric fractures and usually occur due to severe mechanism of injury (20). Of the patients included in 
this study, $12 \%$ had pelvis fracture, and pelvis fractures occurred in $90 \%$ of the patients as a result of severe mechanism of injury in accordance with the literature $(21,22)$. Pediatric pelvis fractures usually heal without needing a surgical operation $(23,24)$. Of the patients included in a study evaluating pelvis fractures, 94\% healed without needing a surgical operation. In this study, in line with the literature, $80 \%$ of the patients were treated without surgical operation (25). Although it is a common fact that pelvis fractures heals itself without needing a surgical operation, it should not be forgotten that bleeding risk is considerably high and usually convoys other organ injuries (26). In the present study, in line with the literature (27), the ratio of other organ injuries was found $65 \%$ while multiple fracture ratio was found $25 \%$.

In other studies evaluating childhood extremity fractures, the upper extremity fracture was more prominent than the lower extremity fracture. It can be concluded that this is because not only motor vehicle accidents but all traumas were evaluated in the study (16). In this study, it was found that most common upper extremity fractures (with a ratio of $42 \%$ ) were humerus (26\%) and radius (26\%) fractures, followed by clavicula (14\%) and ulna (5\%) fractures respectively. In another study evaluating other motor vehicle accidents6, clavicula was more common, while in another study evaluating upper extremity fractures (3), it was found that radius (27\%) was the most common fracture type, followed by humerus (25\%), ulna (18\%), and clavicula (17\%) fractures respectively. In a study evaluating upper extremity fractures with adult patient groups (28), humerus (44\%) and ulna (28\%) fractures were the most common fracture types.

Multiple fractures are mostly associated with severe mechanism of injury, and their incidence ratio varies between 1.7 to $23 \%$ in the pediatric age group. 3 In this study, approximately $1 / 3$ of the patients had multiple fractions and of this cases, $60 \%$ had severe mechanism of injury. Patients with upper extremity fractures were mostly treated with plaster and air splint, while patients with lower extremity and multiple fractures were treated mostly with surgical operations.

Compound fractures have considerably high morbidity and mortality possibilities requiring patient to be hospitalized longer along with the high hospitalization costs. Of the compound fractures, $90 \%$ occur as a result of traffic accident. Risk of contamination, infection, nonunion of the fracture, risk of delayed union, neurovascular complications and increased amputation rate increase the significance of the compound fractures for the childhood age group (29). In this study, the ratio of compound fractures was found to be $4 \%$. Of these fracture incidences, $83 \%$ occurred as a result of severe mechanism of injury.
The most substantial limitation is that the study was conducted in a single center. Multi-centered studies are required.

\section{CONCLUSION}

Since the literature analyzing extremity fractures in motor vehicle accidents is very limited, relevant data are also very limited in this regard. In particular, extremity fractures, injuries and additional organ injuries that develop after motor vehicles create a heavy burden on both families and the government in terms of hospitalization and hospital costs, resulted by a critical ratio of casualties. On that account, collecting relevant data of this group of patients is of very high concern in terms of the management of this group of patients, taking precautions to prevent traffic accidents and narrating traffic rules to parents and children via their parents.

\section{ETHICAL DECLARATIONS}

Ethics Committee Approval: Ethics committee approval was received by the medical faculty of Gazi University scientific research ethics committee prior to the study (No: 09.05.2020/ 91610558-604.01.02-).

Informed Consent: Informed consent forms were obtained from the parents of the patients and controls included in this study.

Referee Evaluation Process: Externally peer-reviewed.

Conflict of Interest Statement: The authors have no conflicts of interest to declare.

Financial Disclosure: The authors declared that this study has received no financial support.

Author Contributions: All of the authors declare that they have all participated in the design, execution, and analysis of the paper, and that they have approved the final version.

\section{REFERENCES}

1. Pratt SG, Bell JL. Analytical observational study of nonfatal motor vehicle collisions and incidents in a light-vehicle sales and service fleet. Accid Anal Prev. 2019;129:126-35.

2. 2.The top 10 causes of death: the 10 leading causes of death in the world, 2000 and 2011. Geneva (Switzerland): World Health Organization; updated 2013 (accessed 2011 June 9); Available: www.who.int/mediacentre/factsheets/fs310/en/index.html

3. 3.Rubin G, Peleg K, Givon A, et al. Upper extremity fractures among hospitalized road traffic accident adults. Am J Emerg Med. 2015;33(2):250-3.

4. Ngunde PJ, Akongnwi ACN, Mefire CA, et al. Prevalence and pattern of lower extremity injuries due to road traffic crashes in Fako Division, Cameroon. Pan Afr Med J. 2019;32:53

5. Craig, A., Tran, Y., Guest, R, et al. Psychological impact of injuries sustained in motor vehicle crashes: systematic review and metaanalysis. BMJ open, 2016;6(9):e011993.

6. Wang H, Zhou Y, Liu J, et al. Traumatic fractures as a result of motor vehicle collisions in children and adolescents. Int Orthop. 2018;42(3):625-30. 
7. Omoke N, Ekumankama FO. Incidence and Pattern of Extremity Fractures seen in Accident and Emergency Department of a Nigerian Teaching Hospital. Niger J Surg 2020;26(1):28-34.

8. Carson S, Woolridge DP, Colletti J, et al. Pediatric upper extremity injuries. Pediatr Clin North Am 2006;53(1):41-67.

9. Srinivasan $S$, Chang T. Diagnosis and management of motor vehicle trauma in children: an evidence-based review. Pediatr Emerg Med Pract 2013;10(8):1-26

10. Kuppermann N, Holmes JF, Dayan PS, et al. Pediatric Emergency Care Applied Research Network (PECARN). Identification of children at very low risk of clinically-important brain injuries after head trauma: a prospective cohort study. Lancet 2009;374(9696):1160-70

11. Drucker NA, McDuffie $L$, Groh E, et al. Physical Examination is the Best Predictor of the Need for Abdominal Surgery in Children Following Motor Vehicle Collision. J Emerg Med 2018;54(1):1-7.

12. Nuñez-Samudio V, Jaramillo-Morales J, Landires I. Prevalence and characteristics of child victims in motor vehicle collisions in Panama. Traffic Inj Prev 2016;17(4):391-3

13. Wang $\mathrm{H}$, Zhou $\mathrm{Y}$, Liu J, et al. Traumatic skull fractures in children and adolescents: A retrospective observational study. Injury. 2018;49(2):219-25

14. Uslu MM, Uslu R. Extremity fracture characteristics in children with impulsive/hyperactive behavior. Arch Orthop Trauma Surg. 2008;128(4):417-21.

15. Joeris A, Lutz N, Wicki B, et al. An epidemiological evaluation of pediatric long bone fractures - a retrospective cohort study of 2716 patients from two Swiss tertiary pediatric hospitals. BMC Pediatr. 2014 20;14:314

16. Lempesis $V$, Rosengren $B E$, Nilsson $J \AA \AA$, et al. Time trends in pediatric fracture incidence in Sweden during the period 1950 2006. Acta Orthop. 2017;88(4):440-5

17. Naranje SM, Erali RA, Warner WC Jr,et al. Epidemiology of Pediatric Fractures Presenting to Emergency Departments in the United States. J Pediatr Orthop. 2016;36(4):e45-8.

18. Loder RT, O'Donnell PW, Feinberg JR. Epidemiology and mechanisms of femur fractures in children. J Pediatr Orthop. 2006;26(5):561-6.

19. Engström Z, Wolf O, Hailer YD. Epidemiology of pediatric femur fractures in children: the Swedish Fracture Register. BMC Musculoskelet Disord. 2020 1;21(1):796

20. Zwingmann J, Aghayev E, Südkamp NP, et al. Pelvic Fractures in Children Results from the German Pelvic Trauma Registry: A Cohort Study. Medicine (Baltimore). 2015;94(51):e2325.

21. Niedzielski KR, Guzikiewicz N, Małecki K,et al. Pelvic fractures in children and adolescents in polytrauma and high-energy injuries. Ortop Traumatol Rehabil. 2013;15(1):41-8.

22. Hermans E, Cornelisse ST, Biert J, et al. Paediatric pelvic fractures: how do they differ from adults? Journal of Children's Orthopaedics 2017:1;49-56.

23. Gänsslen AN, Heidari AM. WeinbergFractures of the pelvis in children: a review of the literature. Eur J Orthopaed Surg Traumatol 2013;1-5.

24. Turgut A, Kalenderer O, Gunaydin B,et al. Demographic Characteristics of Paediatric Pelvic Fractures: 10-Years' Experience of Single Paediatric Orthopaedics Clinic. Eurasian J Med 2015;47(2):130-4.

25. Chotai N, Alazzawi S, Zehra SS, et al. Paediatric pelvic fractures: A review of 2 cohorts over 22 years. Injury 2018;49(3):613-7.

26. Tosounidis $\mathrm{TH}$, Sheikh $\mathrm{H}$, Giannoudis PV. Pelvic Fractures in Paediatric Polytrauma Patients: Classification, Concomitant Injuries and Early Mortality. Open Orthop J 2015;9:303-12.

27. Shaath MK, Koury KL, Gibson PD, et al. Associated injuries in skeletally immature children with pelvic fractures. J Emerg Med 2016;51:246-251

28. Landy DC, Norton RA, Barkin JA, et al. Upper extremity fractures in pedestrian versus motor vehicle accidents: an underappreciated concern. lowa Orthop J 2010;30:99-102.

29. Odatuwa-Omagbemi DO. Open fractures: epidemiologica pattern, initial management and challenges in a sub-urban teaching hospital in Nigeria. Pan Afr Med J 2019;33:234 